\title{
Prospektív vizsgálat a sigmoideoscopia diagnosztikai érzékenységének meghatározására vastagbelet infiltráló endometriosisban
}

\author{
Lukovich Péter dr. ${ }^{1}$ - Csibi Noémi dr. ${ }^{2}$ - Brubel Réka dr. ${ }^{2}$ \\ Tari Krisztina ${ }^{1}$. Csuka Szilvia ${ }^{3}$. Harsányi László dr. ${ }^{1}$ \\ Rigó János Jr. dr. ${ }^{2}$ - Bokor Attila dr. ${ }^{2}$ \\ ${ }^{1}$ Semmelweis Egyetem, Általános Orvostudományi Kar, I. Sebészeti Klinika, Budapest \\ ${ }^{2}$ Semmelweis Egyetem, Általános Orvostudományi Kar, I. Szülészeti és Nőgyógyászati Klinika, Budapest \\ ${ }^{3}$ Endomedix Diagnosztikai Központ, Budapest
}

\begin{abstract}
Bevezetés és célkitüzés: A colorectalis rendszert érintő endometriosis ellátása multidiszciplináris laparoszkópos teammel javasolt. A bélinfiltráció preoperatív felismerése ehhez elengedhetetlen. Betegek és módszer: 2009-2015 között prospektíven 383, endometriosissal diagnosztizált betegnél történt sigmoideoscopia. Intraluminalis endometriosis, fali infiltrációra jellemző másodlagos jelek (falmerevség, benyomat, megtöretés, vizsgálat alatti fájdalom, suffusio) kerültek feldolgozásra. Mútéti indikáció esetén a pozitív esetek multidiszciplináris, a negatív esetek nőgyógyász által végzett mütéten estek át. Eredmények: 224 (58,49\%) pozitívnak talált beteg közül 108-nál multidiszciplináris mütét történt, a negatívnak bizonyult esetek közül 135 ginekológiai mútéten esett át. 108-ból 103 betegnél a mütét során is igazolódott a bél érintettsége, míg a negatív esetek közül nyolc esetben volt jelentős bélinfiltráció. Teljes sigmoideoscopiás vizsgálat 43,4\%-ban volt kivitelezhető. Intraluminalis endometriosis 4,91\%-ban, fali merevség 38,39\%ban, benyomat 45,54\%-ban, megtöretés 57,14\%-ban, fájdalom (narkózis nélkül végzett vizsgálatoknál) 26,06\%-ban, suffusio 3,82\%-ban fordult elő. A sigmoideoscopia szenzitivitása: $92,8 \%$, specificitása: $96,2 \%$ volt. Következtetés: A sigmoideoscopia - tapasztalt endoszkópos esetében - kiemelkedő szenzitivitású eszköz a belet infiltráló endometriosis igazolásában. Orv. Hetil., 2017, 158(7), 264-269.
\end{abstract}

Kulcsszavak: sigmoideoscopia, mélyen infiltráló endometriosis, bélinfiltráció, sebészet

\section{Prospective study to determine the diagnostic sensitivity of sigmoidoscopy in bowel endometriosis}

\begin{abstract}
Introduction and aim: In the treatment of colorectal endometriosis a multidisciplinary laparoscopic resection is suggested, for this reason the correct selection of bowel infiltration is essential before surgery. Patients and method: Between 2009 and 2015, 383 sigmoidoscopies were performed in patients with endometriosis. Where mucosal invasion was absent secondary signs (wall rigidity, impression, kinking, pain during the examination, suffusion) were analysed. In endoscopically confirmed cases multidisciplinary surgery was performed, the remaining patients were operated by a gynecologic team only. Results: Endometriosis was endoscopically confirmed in 224 patients (58.49\%), 108 of them underwent multidisciplinary operation, the negative 135 cases received gynaecological surgery. Bowel endometriosis was confirmed in 103 out of 108 cases intraoperatively, while in 8 cases of the sigmoidoscopically negative patients bowel infiltration was diagnosed intraoperatively by the gynaecological team. Complete sigmoidoscopy was performed in $43.47 \%$ of the cases. Intraluminal endometriosis was found in $4.91 \%$, secondary signs as rigidity in $38.39 \%$, impression in $45.54 \%$, kinking in $57.14 \%$, pain (in cases of examination without narcosis) in $26.06 \%$ and suffusion in $3.82 \%$ of the cases was found during sigmoidoscopy. Sigmoidoscopic examination has a $92.8 \%$ specificity and $96.2 \%$ sensitivity in cases of bowel endometriosis. Conclusion: Sigmoidoscopy performed by an experienced gastroenterologist is a highly sensitive examination for the diagnosis of bowel endometriosis.
\end{abstract}

Keywords: sigmoidoscopy, deeply infiltrating endometriosis, bowel infiltration, surgery

Lukovich, P., Csibi, N., Brubel, R., Tari, K., Csuka, Sz., Harsányi, L., Rigó, J. Jr., Bokor, A. [Prospective study to determine the diagnostic sensitivity of sigmoidoscopy in bowel endometriosis]. Orv. Hetil., 2017, 158(7), $264-269$.

(Beérkezett: 2016. november 8.; elfogadva: 2016. december 9.) 
$\mathrm{Az}$ endometriosis egy ismeretlen etiológiájú krónikus megbetegedés, amelynél az endometriumhoz hasonló mirigy- és stromaszövet-proliferáció figyelhető meg a méh üregén kívül. Az utóbbi két évtizedben a betegség gyakoribbá vált, s az endometriosis miatt operált betegek száma is jelentősen megemelkedett. Gyakoriságát a reproduktív korú női populációban 6-10\% közé teszik [1$3]$. Külön entitásként elkülönítik az összes eset körülbelül 20\%-át kitevő $[4,5]$ mélyen infiltráló endometriosist (deep infiltrating endometriosis - DIE), amely esetén az elváltozás a peritoneum szintjétől $5 \mathrm{~mm}$-nél mélyebbre terjed $[6,7]$.

$\mathrm{Az}$ endometriosis a hasüregben bárhol előfordulhat: bár leggyakrabban a kismedencei szervek érintettek, de a hasüreg felső részében is megjelenhet, így nem ritka a rekeszen felismert endometriosis, de májból [8] és gyomorból [9] is történt már endometriomaeltávolítás. A mélyen infiltráló endometriosis elsősorban a kismedence hátsó részén (sacrouterin szalag, spatium rectovaginalis) fordul elő, de érintheti a kismedence elülső régióját is: megjelenhet a plica vesicouterinán és infiltrálhatja a húgyhólyag izomzatát is, sőt a kismedence lateralis falát infiltráló elváltozás érintheti az ott futó szomatikus idegeket (plexus hypogastricus inferior) is $[10,11]$.

A megbetegedés a nőgyógyászati szervek mellett körülbelül 14\%-ban az urológiai és mintegy 12-45\%-ban a gastrointestinalis rendszert is érinti [12]. Leggyakoribb tünetei a krónikus kismedencei fájdalom $(74,3 \%)$, dysmenorrhoea $(76,9 \%)$, amely az idő előrehaladtával súlyosbodik, hüvelyt érintő endometriosis okozta dyspareunia, a belek infiltrációja következtében jelentkező haematochesia, székletpasszázszavar, illetve az urológiai szervek érintettsége miatti dysuria, haematuria, illetve ureterkompresszió.

A beleket és/vagy az urológiai szerveket érintő megbetegedés sebészi ellátásában a társszakmák szoros, hoszszú távú és rendszeres együttmúködésére van szükség: az egy ülésben végzett többszervi beavatkozás a betegnek kisebb megterhelést jelent, és összességében kisebb az anyagi ráfordítás az egészségügy részérôl is. Ezért a világon a betegség megoldására egyre több helyen multidiszciplináris teamek alakulnak: a nőgyógyász mellett sebész és urológus laparoszkópos sebész is részt vesz a mütétben.

A jelenleg rutinszerúen alkalmazott vizsgálatok szenzitivitása és specificitása a bél érintettségének preoperatív igazolásában alacsony. Pedig ez utóbbi mind a beteg, mind a mútéti team szempontjából fontos lenne. Bélérintettség esetén ugyanis a betegnek a mütéti előkészítés során bélelőkészítésben kell részesülnie, illetve a mütétben a sebésznek is részt kell vennie.

2009-ben a Semmelweis Egyetemen multidiszciplináris műtéti team alakult az endometriosisban szenvedó betegek ellátására, amelynek során prospektív vizsgálat indult a sigmoideoscopiás vizsgálat diagnosztikai hatékonyságának megítélésére.

\section{Betegek és módszer}

2009. augusztus 20. és 2015. augusztus 19. között prospektív módon minden nőgyógyászati vizsgálat során felismert endometriosisban szenvedő betegnél preoperatívan rutinszerúen sigmoideoscopos vizsgálatot végeztünk a bélérintettség igazolására, illetve kizárására. A vizsgálatot minden esetben ugyanaz a több mint 15 éves endoszkópos tapasztalattal rendelkező sebész-gasztroenterológus végezte. A vizsgálat előtt a betegek szabályos kolonoszkópos előkészítést kaptak, és az endoszkópia során az eszközt $50 \mathrm{~cm}$ magasságig vezettük. Azoknál a betegeknél, akik azt kérték, a vizsgálat propofolnarkózisban történt.

Vizsgáltuk, hogy milyen százalékban volt sikeres a vizsgálat, illetve meghatároztuk az endometriosisra jellemző eltérések elhelyezkedésének helyét az anustól mérve.

Az endoszkópia által pozitívnak talált betegek amennyiben mütéti indikáció állt fenn (fertilitási zavar, fájdalom, vastagbél szignifikáns szúküulete, ureterkompresszió) - multidiszciplináris mútéten, míg a negatív esetek csak nőgyógyász által végzett mútéten estek át. A vizsgálatban szereplő betegeknél az operáló team tagjai (nőgyógyász, sebész) ugyanazok voltak.

A vizsgálatot a TUKEB 162/2016 számmal engedélyezte.

\section{Eredmények}

A betegek átlagéletkora 31,2 év volt, a legfiatalabb beteg 21 , míg a legidősebb 41 éves volt. A vizsgált betegek 7\%-a korábban laparotomiából végzett, illetve 54\%-a - 1-6 alkalommal - laparoszkópos nőgyógyászati mútéten esett át.

A 383 megvizsgált beteg közül 224 betegnél (58,49\% esetében) találtunk a sigmoideoscopia során endometriosisra jellemző elváltozásokat. A teljes sigmoideoscopiás vizsgálat csupán az esetek 43,4\%-ában volt kivitelezhető. A sikertelenség leggyakoribb okai a jelentős megtöretés, illetve szúkület és a fájdalom voltak. Utóbbi esetében, ha a diagnózis felállítható volt, nem forszíroztuk az eszköz továbbvezetését.

A pozitív esetek közül mindössze 11 betegnél (4,91\%) volt látható intraluminalisan endometriosis, vagyis a lumenben megjelenő nodularis, puha, vérzékeny szövetszaporulat (1. ábra). A maradék 95\%-ban csak másodlagos jelek voltak láthatók: megtöretés $(57,14 \%)$ (2. ábra), stenosis (benyomat) $(45,54 \%)$ (3. ábra), fali merevség $(38,39 \%)$, fájdalom (nem narkózisban végzett vizsgálatoknál: 280 betegból 73-nál) 26,06\%, míg submucosalis suffusio $3,82 \%$ (4. ábra).

A pozitív esetek közül a cikk megírásáig 108 beteg esett át multidiszciplináris laparoszkópos műtéten. (A pozitívnak bizonyult betegek egy része még nem került műtétre, nem állt fenn műtéti indikáció, vagy elutasította a mútétet.) A multidiszciplináris team által operált 


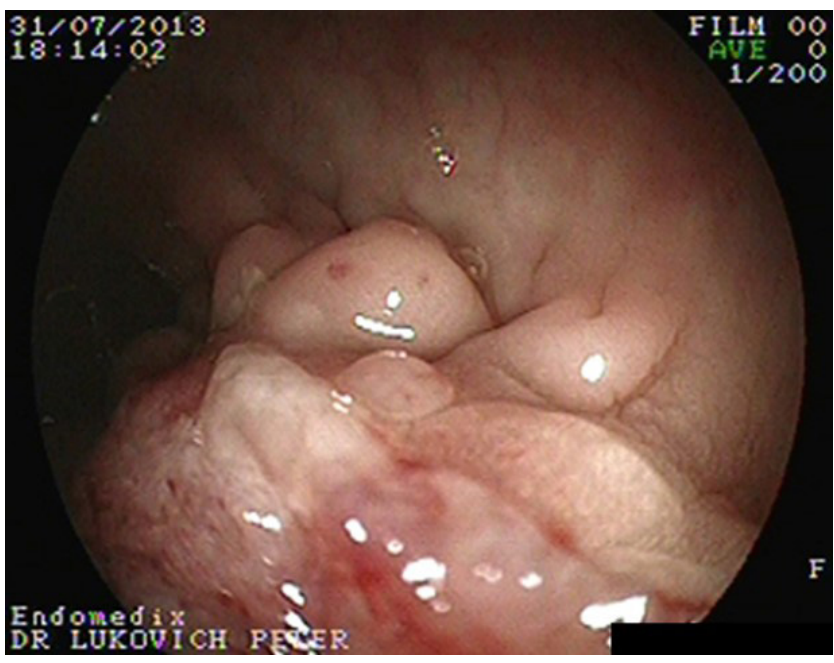

1. ábra Intraluminalisan megjelenő endometriosis a rectumban

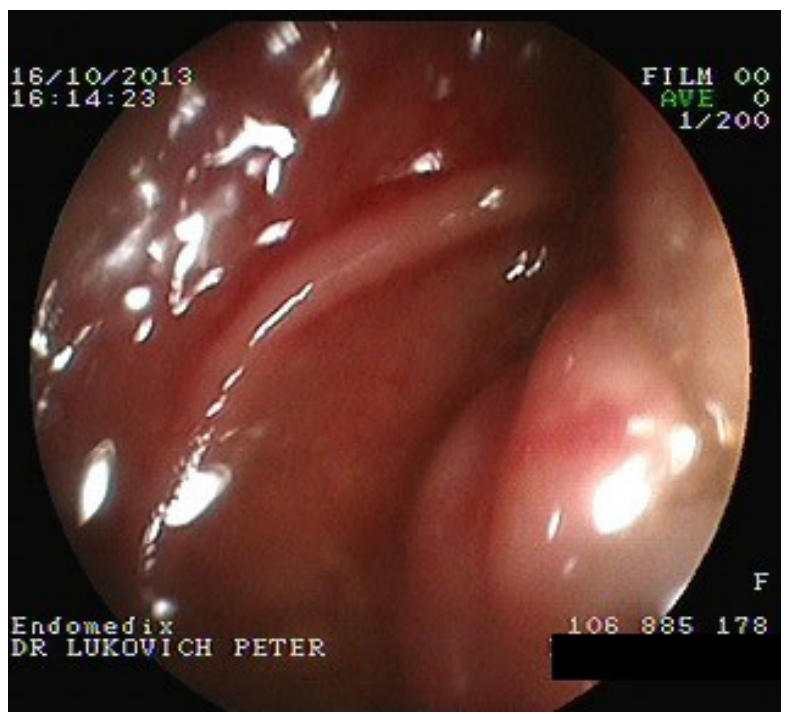

2. ábra

| Belet infiltráló endometriosis okozta jelentős megtöretés

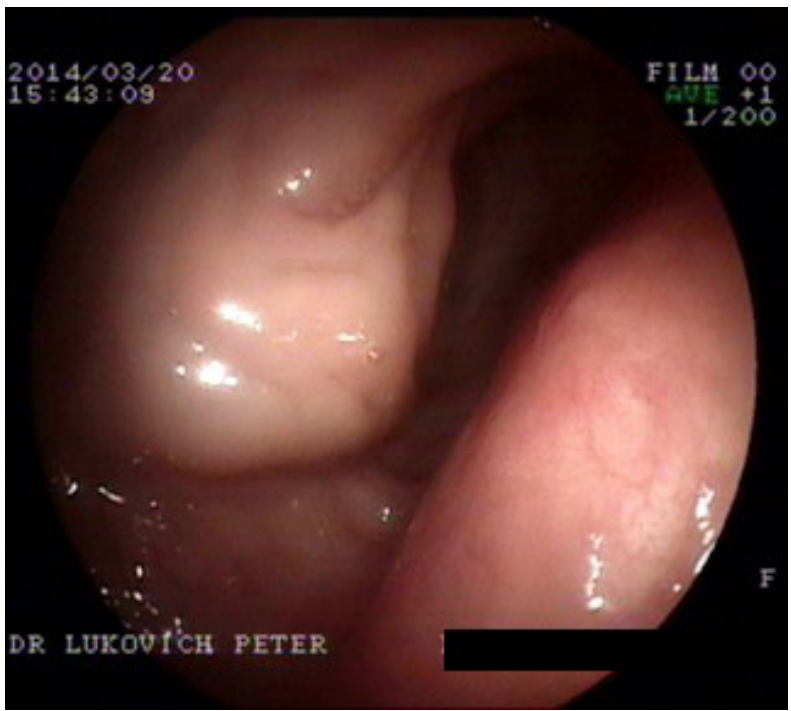

3. ábra

| Bélendometriosis okozta külső benyomat a lumenben

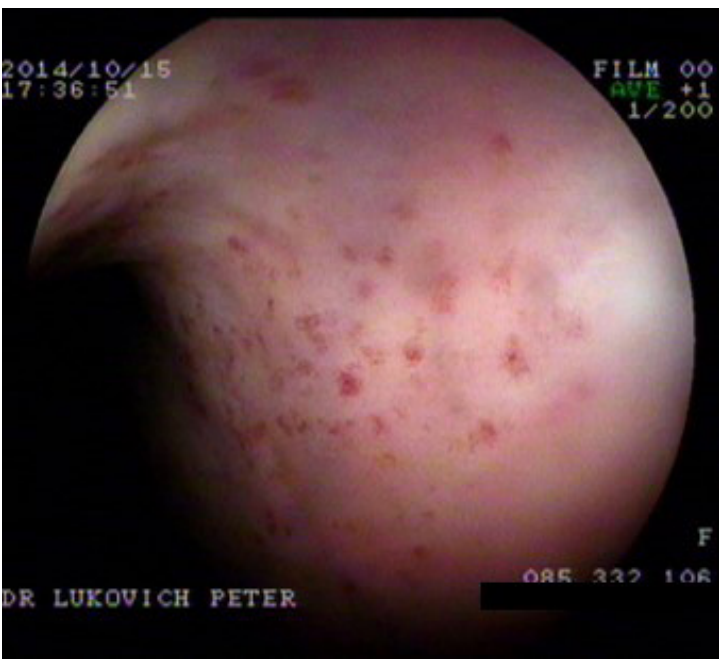

4. ábra

| Suffusiók a submucosában

esetek közül 103 betegnél a mútét során is igazolódott a bél érintettsége (5. ábra). Reszekciót igénylő bélendometriosist nem találtunk: egy esetben ovariumcarcinoma és peritonealis carcinosis igazolódott, két esetben csak a korábbi mútétek okozta adhéziókat találtunk, míg a maradék két esetben a bél endometriosisa shavingtechnikával (a serosafelszín „leborotválásával”) eltávolítható volt.

A sigmoideoscopia során negatívnak bizonyult betegek közül 135 ginekológiai mútéten esett át, ahol azonban nyolc esetben olyan fokú bélinfiltráció igazolódott, amelyet a nőgyógyász shavingtechnikával már nem tudott eltávolítani (6. ábra).

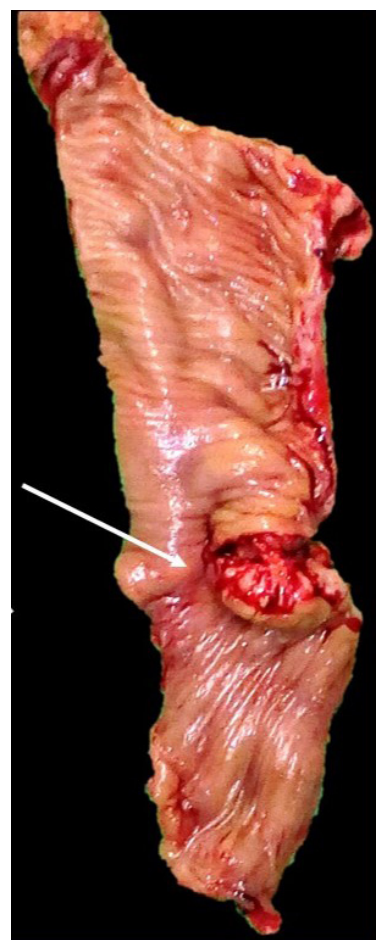

5. ábra

Bélendometriosis miatt reszekált bélszegment felvágva. Az en dometriosiscsomó (fehér nyíllal jelölve) miatt a bélfal merev, nem tud kiegyenesedni, a nyálkahártya ugyanakkor nem érintett 
2009-2015: Endometriosis miatt vizsgálat betegek $(\mathrm{N}=323)$

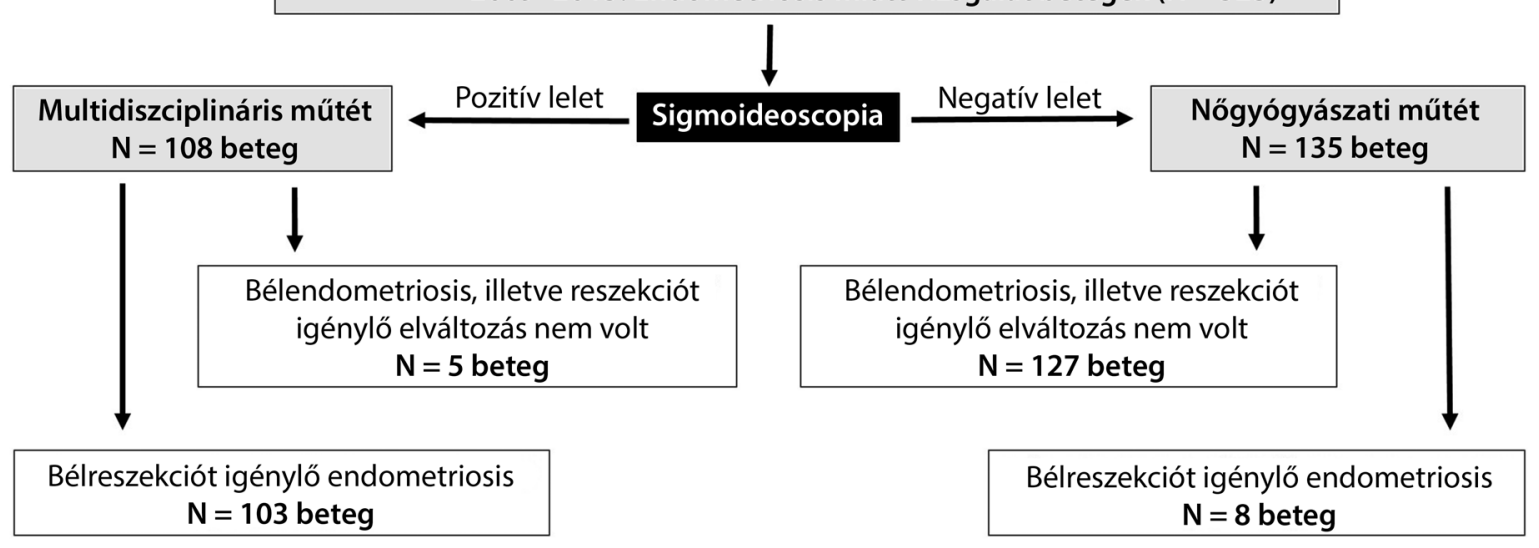

6. ábra $\mid$ A sigmoideoscopiás vizsgálaton átesett betegek megoszlása az endoszkópos és a mútéti lelet alapján

A fenti adatok alapján a sigmoideoscopos vizsgálat szenzitivitása 92,8\%-nak, míg specificitása 96,2\%-nak bizonyult. Nem találtunk különbséget a narkózisban, illetve a nélkül végzett vizsgálatok szenzitivitásában és specificitásában. A pozitív prediktív érték 95,4, a negatív prediktív érték 94,1, a pozitív valószínüségi arány 13,43, a negatív valószínúségi arány 0,06 volt (1. táblázat).

\begin{tabular}{l|l} 
1. táblázat & $\begin{array}{l}\text { A sigmoideoscopos vizsgálat diagnosztikai értéke belet infiltráló } \\
\text { endometriosisnál }\end{array}$ \\
\hline Sigmoideoscopiás vizsgálatok száma & 383 \\
Specificitás & $96,2 \%$ \\
Szenzitivitás & $92,8 \%$ \\
Pozitív prediktív érték & 95,4 \\
Negatív prediktív érték & 94,1 \\
Pozitív valószínúségi arány & 13,43 \\
Negatív valószínúségi arány & 0,06 \\
\hline
\end{tabular}

\section{Megbeszélés}

$\mathrm{Az}$ endometriosis diagnózisának felállítása a bizonytalan hasi panaszok és az ilyen esetekben rutinszerüen alkalmazott vizsgálatok (például hasi ultrahang) alacsony szenzitivitása miatt általában éveket késik [13], és nem ritka, hogy az ileust okozó endometriosis esetében még a mútét során sem sikerül a pontos diagnózist felállítani, és az elváltozást tumornak tartják [14]. Az első tünetek jelentkezésétől számítva Németországban és Ausztriában például átlagosan 10 év [15], Norvégiában 6 év [16], míg Magyarországon 3,9 év telik el [17]. Pedig a korai diagnózis fontos volna, mivel a gyakran igen súlyos panaszokat okozó mélyen infiltráló endometriosis kedvezőtlenül befolyásolja a betegek életminőségét, növeli az egészségügyi kiadásokat és a csökkent munkaképesség miatt jelentős gazdasági kihatása is van [18].

Mint minden betegség esetében, az endometriosisnál is olyan kivizsgálási protokoll lenne az ideális, ami egy- szerű, olcsó és a beteg számára nem megterhelő, nagy szenzitivitással és specificitással rendelkező vizsgálat(oka)t tartalmaz. Az endometriosis esetében arra is választ kellene adjon, hogy érintett-e a gastrointestinalis és/vagy a húgyúti rendszer. Ezek preoperatív ismerete azért fontos, mert jelentős költség- és időmegtakarítást eredményez, ha csak azokban a mútétekben vesz részt a multidiszciplináris team megfelelő tagja, amelyben szakértelmére szükség van.

Amennyiben a bimanuális nőgyógyászati vizsgálat alapján endometriosis gyanúja merül fel, a pontos diagnózis felállítására a világon leggyakrabban alkalmazott módszer a transvaginalis ultrahang- és az MR-vizsgálat. Habár a vizsgálóeljárások közül a $\mathrm{CT}$, virtuális kolonoszkópia [19] és akár az irrigoszkópia [20] is szóba jönne, a fertilis korú, gyakran nullipara nők miatt ezeknek a rutinszerú alkalmazása a sugárterhelés miatt nem javasolt. A bélfalban, illetve a bélfalon kívül elhelyezkedő elváltozások diagnózisánál a rectalis ultrahangvizsgálat jó szenzitivitással bír, de biztonsággal csak $12-13 \mathrm{~cm}$ magasságig használható, és a szúkület, illetve megtöretés miatt gyakran még ez a magasság sem érhető el az eszköz számára. Emellett összességében a vizsgálattól nem is várható magas szenzitivitás, mivel a belet infiltráló endometriosis több mint 40\%-a 20 cm-nél magasabban helyezkedik el.

A transvaginalis ultrahangvizsgálat szenzitivitása 40 , sebészileg igazolt endometriosisban szenvedő beteg retrospektív vizsgálata alapján tapasztalatlan vizsgáló esetén mindössze $25 \%$, és még ennek a betegségnek a felismerésében tapasztalattal bíró vizsgáló esetén is csak $78 \%$. A belek érintettsége szempontjából fontos retrocervicalis és rectosigmoidealis területek diagnosztikájában az eredmények még rosszabbak [21], és a proximálisabb bélszakaszok megítélésében a vizsgálóeljárás szenzitivitása még ennél is alacsonyabb.

Az MRI érzékenységéről releváns információt egy 2006-ban megjelent metaanalízisből kaphatunk, ahol 20 tanulmány 1819 betegének adatát dolgozták fel. A vizs- 
gálat szenzitivitását és specificitását az endometriosis elhelyezkedése szerint vizsgálták, és a következő eredményeket találták: húgyhólyag esetében 0,64 és 0,98, belek esetében 0,84 és 0,97 , a Douglas-ür esetében 0,89 és 0,94 , a rectosigmoidealis átmenetnél 0,83 és 0,88 , a rectovaginalis területen 0,77 és 0,95 , a sacrouterin szalagnál 0,85 és 0,80 , míg a vagina esetén 0,82 és 0,82 voltak. Összességében a szenzitivitás 0,83 , a specificitás 0,90 volt [22]. Bár több közlemény szerint az MR- és CTvizsgálat nagy szenzitivitású vizsgálóeljárás, saját tapasztalataink szerint nem alkalmas a bélinfiltráció pontos felismerésére, amit alátámasztani látszik az, hogy az irodalomban eddig ismertetett 17 , vastagbélileus miatt operált beteg egyikénél sem sikerült pontos diagnózist segítségükkel preoperatívan felállítani [23].

Az endometriosis a hasüregben elhelyezkedő minden bélszakaszt érintheti, a vékony- és vastagbélszakaszokat egyaránt, az érintett bélszakaszok gyakoriságuk sorrendjében a következők: rectum $79 \%$, szigmabél 24\%, appendix $19 \%$, terminalis ileum $2 \%$, colon descendens és coecum 1-1\%. Természetesen a megbetegedés egyszerre több bélszakaszt is érinthet, sőt az esetek mintegy 50\%ában jellemző a multilocularis megjelenés (az érintett bélszakaszok összege éppen ezért több mint 100\%) [24].

A vastagbél primer megbetegedései esetén egyértelműen kolonoszkópia az elsóként választandó vizsgálóeljárás, s mivel a vastagbél-megbetegedések majdnem 100\%-a intraluminalisan helyezkedik el, így a diagnózis felállítása egyszerü, akár szövettanilag is igazolható. Az endometriosis a peritoneum irányából terjed a bélfal mélyebb rétegeire: szövettani vizsgálat alapján a muscularis mucosát az esetek 64\%-ában, a submucosát 25\%-ban, a mucosát mindössze $11 \%$-ban érinti [25]. Vagyis az esetek mintegy 90\%-ában csak a másodlagos jelek alapján következtethetünk endometriosisra. A prospektív vizsgálat megtervezése során a korábbi specimenek feldolgozásáról szóló cikkek alapján az alacsony mucosainfiltrációs arány miatt nem láttuk értelmét endoszkópos biopsziának, s ezért nem is végeztünk.

A mélységi infiltráció meghatározásának mütéttechnikai jelentősége is van. Amennyiben az elváltozás csak a peritoneumot érinti, úgynevezett shaving alkalmazásával (a peritonealis felszín $\mathrm{CO}_{2}$-lézerrel történő elporlasztása) az endometriosis biztonsággal eltávolítható, míg mélyebb rétegek érintettsége esetében az endometriosis radikális eltávolítása csak a teljes bélfal reszekciójával lehetséges.

Az endometriosis klinikailag hegszövetnek felel meg, ennek köszönhetőek azok a másodlagos jelek, amelyek alapvető fontosságúak a belet infiltráló endometriosis felismeréséhez. Az infiltrált bélszakasz elveszti rugalmasságát, mevevvé válik. Mivel az elváltozás nem körkörös, és az endometrioticus csomó a környező peritonealis területekhez szívósan kitapad, az insufflálás hatására jelentős megtöretés jön létre, ami miatt gyakran az eszköz nem is vezethető tovább. A nagyobb csomók benyomatot okoz- hatnak a bélen. Az insufflálás, az eszköz okozta vongálás a betegnek fájdalmat okoz. A bélendometriosis viszonylag gyakori klinikai jele a haematochesia, ami a hormonális hatásra a bélfalban levő endometriosiscsomó következtében kialakuló intramuralis suffusio, majd a vérnek a lumenbe kerülése okozza.

A prospektív vizsgálat megtervezése során azért döntöttünk a sigmoideoscopia és nem teljes kolonoszkópia mellett, mert a kolonoszkópia az appendix tekintetében nem informatív, s a másodlagos jelek értékelhetősége is kisebb a coecumnál, mint a rectosigmoideum esetében. A proximalis vastagbélen végzett mütéthez nem szükséges feltétlenül béltisztítás, így intraoperatív felismerés esetén is radikális (reszekciós) mútét végezhető. Emellett a sigmoideoscopia idő- és költséghatékonyabb is, illetve a betegek számára kisebb megterhelést jelent.

$\mathrm{Az}$ irodalomban endometriosis miatt végzett kolonoszkópos vizsgálatról csak egy beszámoló lelhető fel, nagyon limitált beteganyagról [26]. Az indikáció általában haematochesia az endometriosisban szenvedő fiatal nőbetegek esetében, s mivel az elváltozás extraluminalis, ezért nagyon gyakori, hogy rutinendoszkópia során nem veszik észre vagy félreértelmezik az endometriosis okozta másodlagos jeleket. A korábbi cikkekben épp ezért alulbecsülték a belet infiltráló endometriosis gyakoriságát [27].

\section{Következtetés}

Mivel az endometriosis a nőgyógyászati szervek mellett az urológiai és gastrointestinalis traktust is érintheti, ezért ellátása komplex feladat. A legjobb eredmény központokban, multidiszciplináris team által végzett laparoszkópos mútétekkel érhető el. A preoperatív pontos diagnózis felállítása ezért különösen fontos. Eredményeink alapján - a másodlagos jelek helyes értelmezésével - a sigmoideoscopia jó szenzitivitással használható a bélinfiltráció megítélésére. Kismedencei bizonytalan fájdalom, haematochesia miatt végzett kolonoszkópia esetén képzett gasztroenterológus a bélendometriosis felismerésével a beteg kezelését jó irányba indíthatja el.

Anyagi támogatás: A közlemény megírása anyagi támogatásban nem részesült.

Szerzôi munkamegosztás: L. P., T. K., Cs. Sz.: Endoszkópos vizsgálatok kivitelezése. L. P., B. A.: A kézirat megírása, a mútétek elvégzése. Cs. N., B. R.: Betegadatok összesítése, statisztika. R. J., H. L.: A kézirat ellenőrzése. A cikk végleges változatát valamennyi szerző elolvasta és jóváhagyta.

Érdekeltségek: A szerzőknek nincsenek érdekeltségeik. 


\section{Irodalom}

[1] Bulletti, C., Coccia, M. E., Battistoni, S., et al.: Endometriosis and infertility. J. Assist. Reprod. Genet., 2010, 27(8), 441-447.

[2] Viganò, P., Parazzini, F., Somigliana, E., et al.: Endometriosis: epidemiology and aetiological factors. Best Pract. Res. Clin. Obstet. Gynaecol., 2004, 18(2), 177-200.

[3] Eskenazi, B., Warner, M. L.: Epidemiology of endometriosis. Obstet. Gynecol. Clin. North Am., 1997, 24(2), 235-258.

[4] Chapron, C., Dubuisson, J. B., Fritel, X., et al.: Operative management of deep endometriosis infiltrating the uterosacral ligaments. J. Am. Assoc. Gynecol. Laparosc., 1999, 6(1), 31-37.

[5] Koninckx, P. R., Martin, D. C.: Deep endometriosis: a conse quence of infiltration or retraction or possibly adenomyosis externa? Fertil. Steril., 1992, 58(5), 924-928.

[6] Kavallaris, A., Banz, C., Chalvatzas, N., et al.: Laparoscopic nerve-sparing surgery of deep infiltrating endometriosis: description of the technique and patients' outcome. Arch. Gynecol. Obstet., 2011, 284(1), 131-135.

[7] Cornillie, F. J., Oosterlynck, D., Lauweryns, J. M., et al.: Deeply infiltrating pelvic endometriosis: histology and clinical significance. Fertil. Steril., 1990, 53(6), 978-983.

[8] Bokor, A., Lukovich, P., Rigó, J. Jr.: Deeply infiltrating endometriosis of the liver and diaphragm: case report. [A májat és a rekeszt érintő endometriosis: esetismertetés.] Magyar Nőorvosok Lapja, 2013, 76(2), 28-30. [Hungarian]

[9] Anaf, V., Buggenhout, A., Franchimont, D., et al.: Gastric endometriosis associated with transverse colon endometriosis: a case report of a very rare event. Arch. Gynecol. Obstet., 2014, 290(6), 1275-1277.

[10] Milingos, S., Protopapas, A., Drakakis, P., et al.: Laparoscopic management of patients with endometriosis and chronic pelvic pain. Ann. N.Y. Acad. Sci., 2003, 997, 269-273.

[11] Darai, E., Thomassin, I., Barranger, E., et al.: Feasibility and clinical outcome of laparoscopic colorectal resection for endometriosis. Am. J. Obstet. Gynecol., 2005, 192(2), 394-400.

[12] Kondo, W., Ribeiro, R., Trippia, C., et al.: Deep infiltrating endometriosis: anatomical distribution and surgical treatment. Rev. Bras. Ginecol. Obstet., 2012, 34(6), 278-284.

[13] Dunselman, G. A., Vermeulen, N., Becker, C., et al.: ESHRE guideline: management of women with endometriosis. Hum. Reprod., 2014, 29(3), 400-412.

[14] Arafat, S., Alsabek, M. B., Almousa, F., et al.: Rare manifestation of endometriosis causing complete recto-sigmoid obstruction: A case report. Int. J. Surg. Case Rep., 2016, 26, 30-33.

[15] Hudelist, G., Fritzer, N., Thomas, A., et al.: Diagnostic delay for endometriosis in Austria and Germany: causes and possible consequences. Hum. Reprod., 2012, 27(12), 3412-3416.

[16] Husby, G. K., Haugen, R. S., Moen, M. H.: Diagnostic delay in women with pain and endometriosis. Acta Obstet. Gynecol. Scand., 2003, 82(7), 649-653
[17] Bokor, A., Koszorus, E., Brodszky, V., et al.: The impact of endo metriosis on quality of life in Hungary. [Az endometriosis hatása az eletminőségre Magyarországon.] Orv. Hetil., 2013, 154(36), 1426-1434. [Hungarian]

[18] Simoens, S., Dunselman, G., Dirksen, C., et al.: The burden of endometriosis: costs and quality of life of women with endometriosis and treated in referral centres. Hum. Reprod., 2012, 27(5), 1292-1299

[19] Van der Wat, J., Kaplan, M. D., Roman, H., et al.: The use of modified virtual colonoscopy to structure a descriptive imaging classification with implied severity for rectogenital and disseminated endometriosis. J. Minim. Invasive Gynecol., 2013, 20(5), 543-546.

[20] Savelli, L., Manuzzi, L., Coe, M., et al.: Comparison of transvaginal sonography and double-contrast barium enema for diagnosing deep infiltrating endometriosis of the posterior compartment. Ultrasound Obstet. Gynecol., 2011, 38(4), 466-471.

[21] Fraser, M. A., Agarwal, S., Chen, I., et al.: Routine vs. expertguided transvaginal ultrasound in the diagnosis of endometriosis: A retrospective review. Abdom. Imaging, 2015, 40(3), 587-594.

[22] Medeiros, L. R., Rosa, M. I., Silva, B. R., et al.: Accuracy of magnetic resonance in deeply infiltrating endometriosis: a systematic review and meta-analysis. Arch. Gynecol. Obstet., 2015, 291(3), 611-621.

[23] Lukovich, P., Csibi, N., Rigó, J. Jr., et al.: Bowel endometriosis: new challenge for gastroenterology and surgery? Three cases of endometriosis caused large bowel ileus and review of the literature. [Belet infiltráló endometriosis: a gasztroenterológia és a sebészet új kihívása? Vastagbélileust okozó endometriosis három esete és irodalmi áttekintés.] Orv. Hetil., 2016, 157(49), 19601966. [Hungarian]

[24] Chapron, C., Chopin, N., Borghese, B., et al.: Deeply infiltrating endometriosis: pathogenetic implications of the anatomical distribution. Hum. Reprod., 2006, 21(7), 1839-1845.

[25] Mabrouk, M., Spagnolo, E., Raimondo, D., et al.: Segmental bowel resection for colorectal endometriosis: is there a correlation between histological pattern and clinical outcomes? Hum. Reprod., 2012, 27(5), 1314-1319.

[26] Kim, K. J., Jung, S. S., Yang, S. K., et al.: Colonoscopic findings and histologic diagnostic yield of colorectal endometriosis. J. Clin. Gastroenterol., 2011, 45(6), 536-541.

[27] Kaufman, L. C., Smyrk, T. C., Levy, M. J., et al.: Symptomatic intestinal endometriosis requiring surgical resection: clinical presentation and preoperative diagnosis. Am. J. Gastroenterol., $2011,106(7), 1325-1332$.

(Lukovich Péter dr., Budapest, Üllői út 78., 1082 e-mail: lukovich66@gmail.com)

\section{ÁLLÁSAJÁNLAT}

\section{A Szent Margit Rendelöintézet keres:}

Börgyógyász, iskolaorvos /csecsemö- és gyermekgyógyász/-, fül-orr-gége, és ortopéd szakorvost azonnali belépéssel, teljes vagy részmunkaidöben akár vállalkozási formában.

Fényképes önéletrajzot a következő email címre várjuk: thomka.gyorgy@obudairendelok.hu 